\title{
Methane dynamics in the subarctic tundra: combining stable isotope analyses, plot- and ecosystem-scale flux measurements
}

\author{
M. E. Marushchak ${ }^{1}$, T. Friborg ${ }^{2}$, C. Biasi ${ }^{1}$, M. Herbst ${ }^{2}$, T. Johansson ${ }^{2}$, I. Kiepe ${ }^{2}$, M. Liimatainen ${ }^{1}$, S. E. Lind ${ }^{1}$, \\ P. J. Martikainen ${ }^{1}$, T. Virtanen ${ }^{3}$, H. Soegaard ${ }^{2}$, and N. J. Shurpali ${ }^{1}$ \\ ${ }^{1}$ Department of Environmental and Biological Sciences, University of Eastern Finland, PO Box 1627, \\ 70211 Kuopio, Finland \\ ${ }^{2}$ Department of Geosciences and Natural Resource Management, University of Copenhagen, \\ Øster Voldgade 10, 1350 Copenhagen K, Denmark \\ ${ }^{3}$ Department of Environmental Sciences, University of Helsinki, P.O. Box 65, 00014 University of \\ Helsinki, Finland
}

Correspondence to: N. J. Shurpali (narasinha.shurpali@uef.fi)

Received: 27 July 2015 - Published in Biogeosciences Discuss.: 26 August 2015

Revised: 4 January 2016 - Accepted: 20 January 2016 - Published: 2 February 2016

\begin{abstract}
Methane $\left(\mathrm{CH}_{4}\right)$ fluxes were investigated in a subarctic Russian tundra site in a multi-approach study combining plot-scale data, ecosystem-scale eddy covariance (EC) measurements, and a fine-resolution land cover classification scheme for regional upscaling. The flux data as measured by the two independent techniques resulted in a seasonal (May-October 2008) cumulative $\mathrm{CH}_{4}$ emission of 2.4 (EC) and $3.7 \mathrm{~g} \mathrm{CH}_{4} \mathrm{~m}^{-2}$ (manual chambers) for the source area representative of the footprint of the EC instruments. Upon upscaling for the entire study region of $98.6 \mathrm{~km}^{2}$, the chamber measured flux data yielded a regional flux estimate of $6.7 \mathrm{~g} \mathrm{CH}_{4} \mathrm{~m}^{-2} \mathrm{yr}^{-1}$. Our upscaling efforts accounted for the large spatial variability in the distribution of the various land cover types (LCTs) predominant at our study site. Wetlands with emissions ranging from 34 to $53 \mathrm{~g} \mathrm{CH}_{4} \mathrm{~m}^{-2} \mathrm{yr}^{-1}$ were the most dominant $\mathrm{CH}_{4}$-emitting surfaces. Emissions from thermokarst lakes were an order of magnitude lower, while the rest of the landscape (mineral tundra) was a weak sink for atmospheric methane. Vascular plant cover was a key factor in explaining the spatial variability of $\mathrm{CH}_{4}$ emissions among wetland types, as indicated by the positive correlation of emissions with the leaf area index (LAI). As elucidated through a stable isotope analysis, the dominant $\mathrm{CH}_{4}$ release pathway from wetlands to the atmosphere was plantmediated diffusion through aerenchyma, a process that discriminates against ${ }^{13} \mathrm{C}-\mathrm{CH}_{4}$. The $\mathrm{CH}_{4}$ released to the atmosphere was lighter than that in the surface porewater, and
\end{abstract}

$\delta^{13} \mathrm{C}$ in the emitted $\mathrm{CH}_{4}$ correlated negatively with the vascular plant cover (LAI). The mean value of $\delta^{13} \mathrm{C}$ obtained here for the emitted $\mathrm{CH}_{4},-68.2 \pm 2.0 \%$, is within the range of values from other wetlands, thus reinforcing the use of inverse modelling tools to better constrain the $\mathrm{CH}_{4}$ budget. Based on the IPCC A1B emission scenario, a temperature increase of $6.1^{\circ} \mathrm{C}$ relative to the present day has been predicted for the European Russian tundra by the end of the 21st Century. A regional warming of this magnitude will have profound effects on the permafrost distribution leading to considerable changes in the regional landscape with a potential for an increase in the areal extent of $\mathrm{CH}_{4}$-emitting wet surfaces.

\section{Introduction}

The Arctic tundra, underlain by permafrost, covers 9.2 million $\mathrm{km}^{2}$, i.e., $8 \%$ of the global land area, and the large carbon pools stored in Arctic soils are extremely vulnerable to global warming (McGuire et al., 2012). The Arctic region can greatly alter the atmospheric concentrations of $\mathrm{CO}_{2}$ (carbon dioxide) and $\mathrm{CH}_{4}$ (methane) through feedback mechanisms (Post et al., 2009). Inverse modelling results based on measurements of concentrations and stable isotope composition of $\mathrm{CH}_{4}$ have already proved the importance of highlatitude wetlands as global $\mathrm{CH}_{4}$ sources (Riley et al., 2011). 
For example, the spike in the global mean atmospheric $\mathrm{CH}_{4}$ concentration in 2007 has been attributed to anomalously high summer temperatures experienced by these ecosystems during that year (Dlugokencky et al., 2011). Despite the large areal extent, the Russian tundra region is relatively less explored as far as its biogeochemical functioning is concerned. According to the latest estimates, this region is presently considered to be a net carbon dioxide $\left(\mathrm{CO}_{2}\right)$ sink and a source of atmospheric $\mathrm{CH}_{4}$. Although $\mathrm{CO}_{2}$ flux represents the major component in the total $\mathrm{C}$ flow between tundra ecosystems and the atmosphere, $\mathrm{CH}_{4}$ is equally important owing to its 28 times higher global warming potential over a 100 -year time horizon (IPCC, 2014).

In the Arctic, $\mathrm{CH}_{4}$ is mostly emitted from wetlands (Heikkinen et al., 2004; Mastepanov et al., 2008) and from lakes and ponds (Walter et al., 2008). On the whole, there is a general consensus that the Arctic region is a moderate $\mathrm{CH}_{4}$ source (19 $\mathrm{Tg} \mathrm{yr}^{-1}$; McGuire et al., 2012). However, this estimate is fraught with uncertainty ranging from 8 and $29 \mathrm{Tg} \mathrm{yr}^{-1}$ (McGuire et al., 2012). This is attributed to the flux variability across time and space that is poorly characterized as yet. Methane exchange is unevenly distributed across the landscape (hot spots; Walter et al., 2006) and may occur during short periods of time (Mastepanov et al., 2008). For reliable estimates of $\mathrm{CH}_{4}$ balance, continuous measurements made across all important constituent land cover types are required. The ideal way to achieve this is to apply chamber and eddy covariance techniques in parallel. Such an approach has, however, rarely been adopted in Arctic investigations (Parmentier et al., 2011; Sachs et al., 2008). The eddy covariance method allows continuous ecosystem-scale measurement of methane exchange, while chamber techniques aid in a proper characterization of the inherent site spatial variability. The two methods employed simultaneously help improve the accuracy of the regional flux estimates, as has been shown for $\mathrm{CO}_{2}$ at this site (Marushchak et al., 2013).

In addition to increasing the accuracy of flux estimates, processes underlying $\mathrm{CH}_{4}$ dynamics need to be better understood. This is important for developing process-based biogeochemical models with an ability to simulate present and future $\mathrm{CH}_{4}$ fluxes (Riley et al., 2011). In this respect, stable isotope analyses of $\mathrm{CH}_{4}$ have been useful as they provide valuable information on mechanisms of $\mathrm{CH}_{4}$ production, transport, and oxidation (Chanton, 2005; Chanton et al., 2005; Popp et al., 1999). The two dominant $\mathrm{CH}_{4}$ production pathways, hydrogenotrophic $\left(\mathrm{CO}_{2}\right.$ reduction) and acetoclastic methanogenesis (acetate fermentation), discriminate differently against ${ }^{13} \mathrm{C}$-isotope (Chanton et al., 2005). Also, $\mathrm{CH}_{4}$ oxidation by methanotrophic bacteria favours the ${ }^{12} \mathrm{C}$-isotope, leaving the residual $\mathrm{CH}_{4}$ enriched with ${ }^{13} \mathrm{C}$ (Whiticar, 1999). Isotopic fractionation of $\mathrm{CH}_{4}$ released from wetland to the atmosphere depends on the mode of its transport. While ebullition and diffusion through the air-water interface cause practically no fractionation, diffusive transport through plant aerenchyma is slower for ${ }^{13} \mathrm{C}_{-} \mathrm{CH}_{4}$, resulting in lighter $\mathrm{CH}_{4}$ being emitted from the plants compared to that in sediment porewater (Chanton et al., 2005). Knowledge on the isotopic composition of $\mathrm{CH}_{4}$ from various ecosystem types is also important for top-down modelling in which the aim is to determine the relative contribution of different emission sources to the atmospheric $\mathrm{CH}_{4}$ content (Riley et al., 2011). Data on isotopic composition of $\mathrm{C}$ in peatland $\mathrm{CH}_{4}$ emissions are sparse, especially from the Russian tundra ecosystems (Sapart et al., 2013). A more detailed characterization of $\mathrm{CH}_{4}$ emissions is highly relevant to better constrain global $\mathrm{CH}_{4}$ sinks and sources, particularly in view of the growing emphasis on the role of northern peatlands in the global C cycle.

The present-day trends have revealed that the permafrost temperatures in the discontinuous zone have risen by $2{ }^{\circ} \mathrm{C}$ and the southern boundary of permafrost has retreated northwards in the Russian Arctic (Romanovsky et al., 2010). Changes in permafrost extent and active layer thickness affect vegetation composition (Christensen, 2004) and $\mathrm{CH}_{4}$ flux (Johansson et al., 2006) from northern wetlands. In a study on permafrost dynamics of the Russian tundra (Anisimov, 2007), permafrost temperatures have been projected to increase by $2-3{ }^{\circ} \mathrm{C}$ by 2050 with a $15-25 \%$ increase in the active layer thickness and a $25 \%$ increase in the $\mathrm{CH}_{4}$ emissions from the northern Russian wetlands. Such projections can be improved with a robust estimate of the magnitude of $\mathrm{CH}_{4}$ fluxes, their spatial and temporal variability, and underlying mechanisms.

Our aim here is to provide an estimate of $\mathrm{CH}_{4}$ fluxes as measured by two independent measurement techniques in a subarctic Russian tundra region and to deepen our understanding of the factors regulating methane exchange in this environment. To investigate methane fluxes and underlying mechanisms in the Russian Arctic at various scales (from plots to landscape), we used a set of methodological tools including stable isotope investigations, EC- and chamberbased flux measurement techniques and regional upscaling by a fine-scale QuickBird satellite image-based land cover classification scheme. We report here a full year of $\mathrm{CH}_{4}$ measurements by static chambers and gas gradient methods. These methods were complemented by fluxes measured using the EC technique from early spring to autumn in 2008. To the best of our knowledge, this is one of the rare studies that employs multi-level approaches on $\mathrm{CH}_{4}$ dynamics over various temporal and spatial scales in the Russian Arctic environment.

\section{Materials and methods}

\subsection{Site description}

This study was conducted in the subarctic tundra of the Komi Republic, Northeast European Russia. The measurement site is located near the village of Seida $\left(67^{\circ} 03^{\prime} 21^{\prime \prime} \mathrm{N}\right.$, 


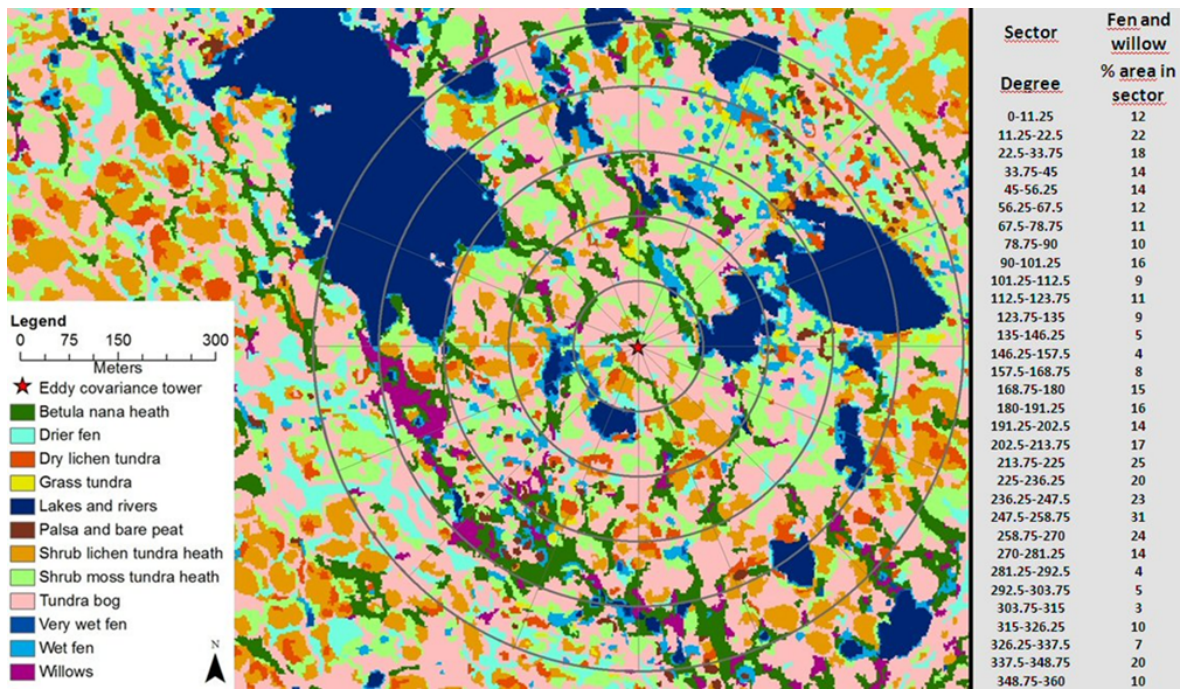

Figure 1. Land cover classification of the field site employing QuickBird satellite imagery. The eddy covariance (EC) tower is indicated by a star, concentric lines drawn around the tower at $100 \mathrm{~m}$ intervals represent the EC footprint area. Areal coverage of fen and willow land cover types in different sectors from the EC tower is shown in a table to the right of the figure, zero refers to north.

$62^{\circ} 56^{\prime} 45^{\prime} \mathrm{E}, 100 \mathrm{~m}$ a.s.1.) and situated in the discontinuous permafrost zone just above the northern treeline. Based on the long-term climatic data from the Vorkuta station $\left(67^{\circ} 48^{\prime} \mathrm{N}, 64^{\circ} 01^{\prime} \mathrm{E}, 172 \mathrm{ma}\right.$ a. s. 1.) for the $1977-2006$ period, the mean annual temperature in the region is $-5.6^{\circ} \mathrm{C}$, with January being the coldest month (mean temperature $-20.4^{\circ} \mathrm{C}$ ) and July the warmest one (mean temperature $13.0^{\circ} \mathrm{C}$ ), and an annual precipitation of $501 \mathrm{~mm}$. A more detailed description of the site as well as information on permafrost and carbon storage of the tundra soils of this region can be found in Hugelius et al. (2011), Marushchak et al. (2011, 2013) and Biasi et al. (2013).

A high-resolution QuickBird satellite image (Fig. 1) was used to map the distribution of the various land cover types (LCTs) of the study area of $98.6 \mathrm{~km}^{2}$ (Hugelius et al., 2011; Marushchak et al., 2013). In terms of areal coverage, the tundra heath $(58 \%)$ and tundra bog vegetation $(24 \%)$ found especially on permanently frozen peat plateaus are the dominant ecosystem types in the region followed by willow stands $(9 \%)$, and various fen ecosystems $(6 \%)$. The peat plateaus are spotted by unvegetated, patterned ground features - referred to hereafter as bare peat circles - which have been studied by Repo et al. (2009) as they were found to emit large amounts of $\mathrm{N}_{2} \mathrm{O}$ to the atmosphere. The willow stands are typically $0.5-1.5 \mathrm{~m}$ in height and grow on low-lying areas with waterlogged soils. The dominating plant species besides various Salix species are Carex aquatilis Wahl., Betula nana L., Eriophorum russeolum Fries and Comarum palustre $\mathrm{L}$. Fens are found on littoral areas of thermokarst lakes and on the edges of the frozen peat plateau peatlands. They are mesotrophic and can be divided according to the dominant vascular plant species into Eriophorum fens (domi- nating vascular plant species Eriophorum russeolum Fries) and Carex fens (dominating vascular plants Carex aquatilis Wahl. and Comarum palustre L.). Sphagnum species dominate the ground layer and form a dense mat floating on the water together with vascular plant roots. Small lakes, mostly of thermokarst origin, cover a minor part of the landscape $(1 \%)$.

\subsection{Instrumental setup and methodology}

\subsubsection{Plot-scale $\mathrm{CH}_{4}$ flux measurements at terrestrial land cover types}

Ten land cover types, each with three replicate measuring plots, were established for the determination of $\mathrm{CH}_{4}$ fluxes from the soil surface, three of them on water-logged wetlands, three on peat plateau and four on upland tundra. Fluxes of $\mathrm{CH}_{4}$ were determined using the methodology described in detail for nitrous oxide fluxes by Marushchak et al. (2011). Fluxes were measured by the static chamber technique 11-16 times during the snow-free season from early July to mid-October 2007 and 16-21 times during the snowfree season from late May-early July until the beginning of October 2008. In addition, $\mathrm{CH}_{4}$ fluxes were measured 2-5 times per plot during the snow cover period in January-June with a snow-gradient method (Merbold et al., 2013). The $\mathrm{CH}_{4}$ concentrations in the collected gas samples were analysed within three months from sampling using a gas chromatograph equipped with a flame ionization detector (Agilent 6890N, Agilent Technologies Deutschland, Böblingen, Germany). A leakage test with a high $\mathrm{CH}_{4}$ concentration $(15 \mathrm{ppm})$ showed that the reduction in gas concentration in the sample vials over 2 months was less than $1 \%$ (data not 
shown). Flux calculation and the criteria to accept or reject fluxes for further analysis are described in Marushchak et al. (2011). Water table level (WT), active layer depth (AL), soil temperature at 2 and $25 \mathrm{~cm}$ depths and vascular leaf area index (LAI; only in 2008) were monitored at different land cover types by manual and continuous measurements as described by Marushchak et al. $(2011,2013)$. The adjustment of moss surface to water table fluctuations on willow and fen microsites was monitored in 2008 by a measuring pole pushed through the peat profile down to the mineral soil.

\subsubsection{Lake methane emission measurements}

Release of $\mathrm{CH}_{4}$ by diffusion and ebullition pathways was studied in three thermokarst lakes from July to August 2007 (11 samplings between days 191-239) and from June to October 2008 (19 samplings between days 182-276). The area of the studied lakes was $0.03-3$ ha with the maximum depth ranging from 2.0 to $2.6 \mathrm{~m}$ and surface water $\mathrm{pH}$ from 4.6 to 5.5. Diffusive $\mathrm{CH}_{4}$ flux was calculated from $\mathrm{CH}_{4}$ concentration in the surface water and local wind speed using the thin boundary layer (TBL) model (Liss and Slater, 1974). Surface water samples were collected during daytime ( 8 a.m.19 p.m.). The determination of $\mathrm{CH}_{4}$ concentration with a headspace method and flux calculation were carried out as described in Repo et al. (2007). Linear interpolation was used to obtain daily $\mathrm{CH}_{4}$ concentrations. The hourly averaged wind speed measured at $2 \mathrm{~m}$, normalized to $10 \mathrm{~m}$ using a logarithmic wind profile, was used to calculate hourly flux rates. Ebullitive $\mathrm{CH}_{4}$ flux was monitored with permanently installed, submerged funnel gas collectors (Repo et al., 2007). Each lake had 6-7 replicate gas collectors (diameter $0.35 \mathrm{~m}$ ), which were sampled concurrently with surface water sampling. Gas samples were stored and analysed as described above.

\subsection{Temporal extrapolation of plot-scale $\mathrm{CH}_{4}$ fluxes}

The temperature dependence of $\mathrm{CH}_{4}$ flux was used to produce daily $\mathrm{CH}_{4}$ exchange rates during the snow-free period for the land cover types with large $\mathrm{CH}_{4}$ fluxes: willow stands, Carex fen and Eriophorum fen. Regression functions based on air temperature and peat temperatures at 2 and $25 \mathrm{~cm}$ were tested, and the best fit was obtained with temperature at $25 \mathrm{~cm}$. Addition of a water table term improved the model fit in 2007 (helped explain $20 \%$ additional variation in the flux data) and resulted in a more realistic seasonal pattern, so the following function was used:

$$
\begin{aligned}
& \mathrm{CH}_{4} \text { flux }\left(\mathrm{g} \mathrm{CH}_{4}-\mathrm{Cm}^{-2} \mathrm{~d}^{-1}\right) \\
& =\alpha \times \beta^{(T-10) / 10} \times \exp ^{(\gamma \times \mathrm{WT})},
\end{aligned}
$$

where $T$ is the soil temperature at $25 \mathrm{~cm}\left({ }^{\circ} \mathrm{C}\right)$ and $\mathrm{WT}$ is the water table level $(\mathrm{cm})$. Model parameters were estimated for each measurement plot individually using the SPSS 14.0 statistical software. The regression functions explained $85 \%$ of

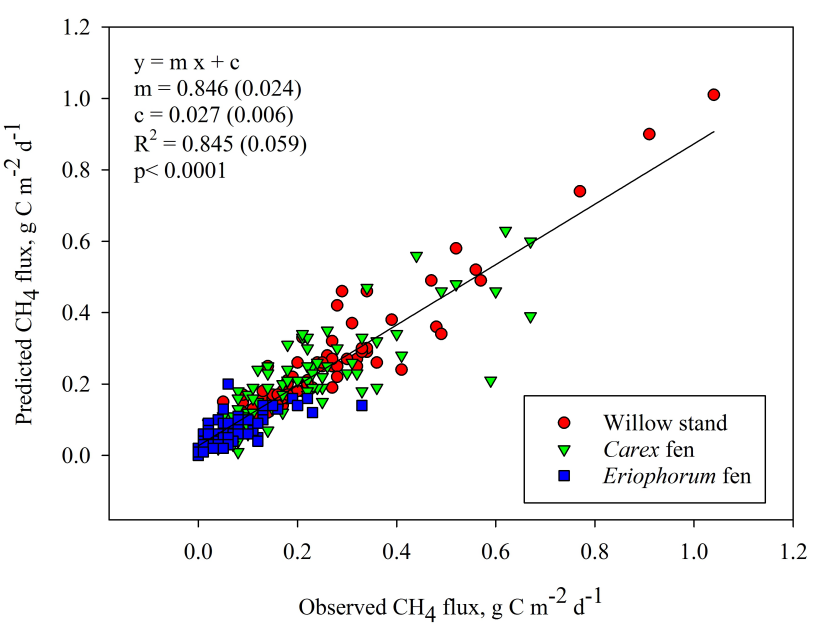

Figure 2. A comparison of observed and predicted $\mathrm{CH}_{4}$ fluxes $(n=254)$ measured using chambers during 2007-2008 from different tundra wetland types in the Seida study site. The solid line represents the linear least-squares fit of the data. Statistics from the linear regression analysis are also shown in the figure.

the overall variability in fluxes across the different vegetation types (Table 1; Fig. 2).

For the remaining terrestrial plots with low emissions and for lakes, $\mathrm{CH}_{4}$ fluxes were integrated over time using linear interpolation for the days between the measurements as described by Marushchak et al. (2011). Linear interpolation was also used for willows and fens for the snow period when the water table levels were not monitored. The annual fluxes were calculated for the period from 6 October 2007 until the termination of measurements on 5 October 2008.

\subsection{Isotope analysis of emitted and porewater $\mathrm{CH}_{4}$}

The $\delta^{13} \mathrm{C}$-values of the emitted and porewater $\mathrm{CH}_{4}$ were determined during summer 2007 and 2008 from the three surface types with high water table and, thus, with a potential for high $\mathrm{CH}_{4}$ release: willow stands, Carex and Eriophorum fens. Gas samples were collected biweekly in 2007 from mid-July until late August (total five times) and twice in 2008, in late June and in early August. Five gas samples were collected for the isotopic analysis during the time of the chamber closure and injected into $35 \mathrm{~mL}$ glass vials (Wheaton) topped with rubber septa and prefilled with $\mathrm{N}_{2}$ gas. Porewater at 5 and $30 \mathrm{~cm}$ depths was sampled from permanently installed gas collectors made out of perforated plastic tubes following Maljanen et al. (2003). A water sample of $30 \mathrm{~mL}$ was taken in a $60 \mathrm{~mL}$ syringe, a similar volume of synthetic $\mathrm{CH}_{4}$-free air was added and the syringe was then shaken for $2 \mathrm{~min}$, after which the gas phase was transferred to a glass vial (Labco Exetainer) prefilled with pure $\mathrm{N}_{2}$. The $5 \mathrm{~cm}$ gas collector was occasionally above water table level, in which case poregas was sampled and transferred directly into a vial. Additionally, porewater was sampled from 4 to 5 
Table 1. Summary of the empirical models used to generate the seasonal $\mathrm{CH}_{4}$ flux estimates for the different wetland land cover types at the Seida study site. These seasonal estimates are based on chamber fluxes measured during the snow-free period. Models were fitted separately for each measurement plot.

\begin{tabular}{lccccc}
\hline Site & Year & $\alpha$ & $\beta$ & $\gamma$ & $R^{2}$ \\
\hline Carex fen $(n=3)$ & 2007 & $0.11-0.26$ & $2.1-7.4$ & $-0.06-0.01$ & $0.18-0.84$ \\
& 2008 & $0.15-0.20$ & $7.4-22.3$ & $-0.02-0.04$ & $0.78-0.83$ \\
Eriophorum fen $(n=3)$ & 2007 & $0.04-0.11$ & $3.3-3.7$ & $-0.09-0.04$ & $0.20-0.82$ \\
& 2008 & $0.06-0.09$ & $5.3-35.3$ & $-0.01-0.09$ & $0.62-0.66$ \\
Willow stand $(n=3)$ & 2007 & $0.14-0.22$ & $1.6-5.1$ & $0.02-0.05$ & $0.77-0.87$ \\
& 2008 & $0.30-0.32$ & $2.3-9.3$ & $-0.01-0.07$ & $0.79-0.94$ \\
\hline
\end{tabular}

depths extending down to 40-60 $\mathrm{cm}$ in June and August 2008 with a steel probe connected to a syringe. Also ambient air samples were collected for isotopic analysis.

Isotope analyses of $\mathrm{CH}_{4}$ were done at the laboratories of the University of Eastern Finland by gas chromatography isotope ratio mass spectrometry (GC-IRMS; Thermo Finnigan Delta XP, Germany) equipped with a preconcentration unit (Precon, Thermo Scientific, Germany; Dorodnikov et al., 2013). If needed, samples were diluted. Values are expressed as $\delta^{13} \mathrm{C}$ relative to VPDB (Vienna Pee Dee Belemnite Standard) using a standard gas with known ${ }^{13} \mathrm{C}$ values. The standard error of five repeated measurements of isotope standard was less than $0.5 \%$ ofor $\mathrm{CH}_{4}$. Methane concentrations of all samples were separately analysed by gas chromatography (Hewlett Packard 5890A) equipped with a flame ionization detector (FID) for $\mathrm{CH}_{4}$ (Mörsky et al., 2008). The Keeling plot method (Pataki et al., 2003) was used to determine the $\delta^{13} \mathrm{C}$-value of emitted $\mathrm{CH}_{4}$. According to this method, the $\delta^{13} \mathrm{C}$ value of the emitted $\mathrm{CH}_{4}$ is obtained by plotting the measured $\delta^{13} \mathrm{C}$ values against the inverse of $\mathrm{CH}_{4}$ concentrations, where the intercept of the linear equation with the $y$ axis is the $\delta^{13} \mathrm{C}$ value of the emitted $\mathrm{CH}_{4}$.

\subsection{EC measurements}

The landscape-scale $\mathrm{CH}_{4}$ fluxes were measured by the EC technique during the period from mid-May to early October 2008. The $\mathrm{CO}_{2}$ fluxes, measured simultaneously with the $\mathrm{CH}_{4}$ flux data presented in this paper, have already been reported in Marushchak et al. (2013) and Kiepe et al. (2013). Fluctuations in the vertical wind speed were measured at a height of $2.75 \mathrm{~m}$ above the ground using a threedimensional sonic anemometer (R3, Gill Instruments Ltd, UK). A quantum cascade laser (QCL) spectrometer was used for $\mathrm{CH}_{4}$ concentration measurements (Aerodyne Inc., USA). The $\mathrm{CH}_{4}$ fluxes were calculated and corrected for theoretical separation between instruments and attenuation of the $\mathrm{CH}_{4}$ signal in the intake tube using the software package, AltEddy version 3.5 (Alterra, University of Wageningen, The Netherlands). Methane fluxes were further corrected for simultaneous flux of $\mathrm{H}_{2} \mathrm{O}$ (Webb et al., 1980). Further data processing and quality control followed the standard methodology of
Aubinet et al. (1999) and Foken et al. (2005). Calculation of the source area for the flux measurements followed the principles described in Soegaard et al. (2000) and Marushchak et al. (2013), where LCTs were based on a QuickBird satellite image classification.

\subsection{Regional $\mathrm{CH}_{4}$ emission}

For area integration of the $\mathrm{CH}_{4}$ fluxes to the landscape and regional level we used a land cover classification (Fig. 1; Hugelius et al., 2011; Marushchak et al., 2013) that was made based on a QuickBird satellite image acquired on 6 July 2007 (QuickBird $^{\odot}$ 2007, Digital Globe; Distributed by Eurimage/Pöyry). The classification procedure is explained in more detail in Virtanen and Ek (2014). The high resolution of the satellite image ( $2.4 \mathrm{~m}$ pixel size, four channels) allowed accurate representation of the heterogeneous landscape, including fens that are distributed across the landscape as narrow stripes or patches (Virtanen and Ek, 2014). The hourly chamber fluxes of different land-cover types were weighted by their relative area contributions to estimate flux values for the EC footprint and for the whole QuickBird area. For rivers, we used a $\mathrm{CH}_{4}$ emission value of $1.33 \mathrm{~g} \mathrm{CH}_{4} \mathrm{~m}^{-2}$ during summer, estimated for a river in the same region by Heikkinen et al. (2004). A zero $\mathrm{CH}_{4}$ balance was assumed for forest stands, sand, and impacted tundra.

\section{Results}

\subsection{Climatic conditions during the study period}

Plot-scale measurements of $\mathrm{CH}_{4}$ fluxes on terrestrial sites and lakes were made primarily during the 2007 and 2008 growing seasons and less frequently during the cold season in between (Fig. 3a and b). A detailed discussion of weather conditions during the study period can be found in Marushchak et al. (2011). In brief, mid-summer temperatures were higher than the long-term averages during both years, and July was hotter in $2007\left(17.9^{\circ} \mathrm{C}\right)$ than in $2008\left(15.8^{\circ} \mathrm{C}\right)$. The amount of precipitation received during the two growing seasons was comparable to the long-term regional precipitation. In 2008, a period from mid-May through early Oc- 

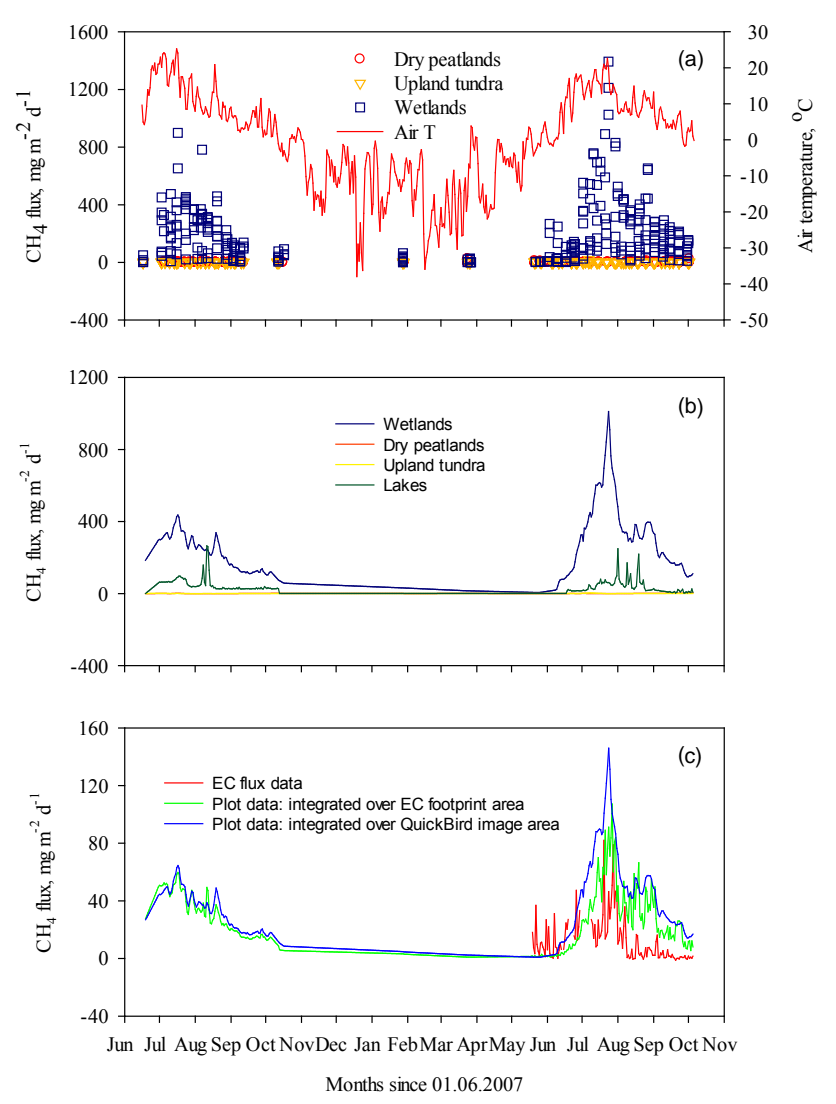

Figure 3. Seasonal distribution of daily values of chamber and EC measured $\mathrm{CH}_{4}$ fluxes during the period from July 2007 to October 2008. Top panel: raw data as measured by the chamber method at dominant terrestrial land cover types (LCTs); Middle panel: daily mean fluxes measured using chambers at terrestrial LCTs and lakes interpolated over the study period; Bottom panel: a comparison of the daily fluxes measured using EC technique with the plot-scale chamber data integrated over the EC footprint area and over the QuickBird map area for the whole study region of $98.6 \mathrm{~km}^{2}$.

tober was covered by simultaneous plot-scale and EC measurements (Fig. 3c). In the beginning of this measurement campaign, there was still a $90 \%$ snow cover and soil temperatures were below the freezing point. By early October, the diurnal average air temperatures had again dropped close to zero and the maximum active layer thickness varied from $41 \mathrm{~cm}$ to greater than $120 \mathrm{~cm}$ depending on the land cover type.

\subsection{Spatial variability in $\mathrm{CH}_{4}$ fluxes}

Based on the plot-scale measurements, wetland sites (willow stands and fens) were the emitters of high amounts of $\mathrm{CH}_{4}$ to the atmosphere throughout the snow-free season (Fig. 3a). The $\mathrm{CH}_{4}$ fluxes increased in the order: Eriophorum fen < Carex fen < willow stands, with LAI of vascular plants explaining $88 \%$ of the differences in fluxes among the sites (Fig. 4). The annual $\mathrm{CH}_{4}$ emissions from these wet-
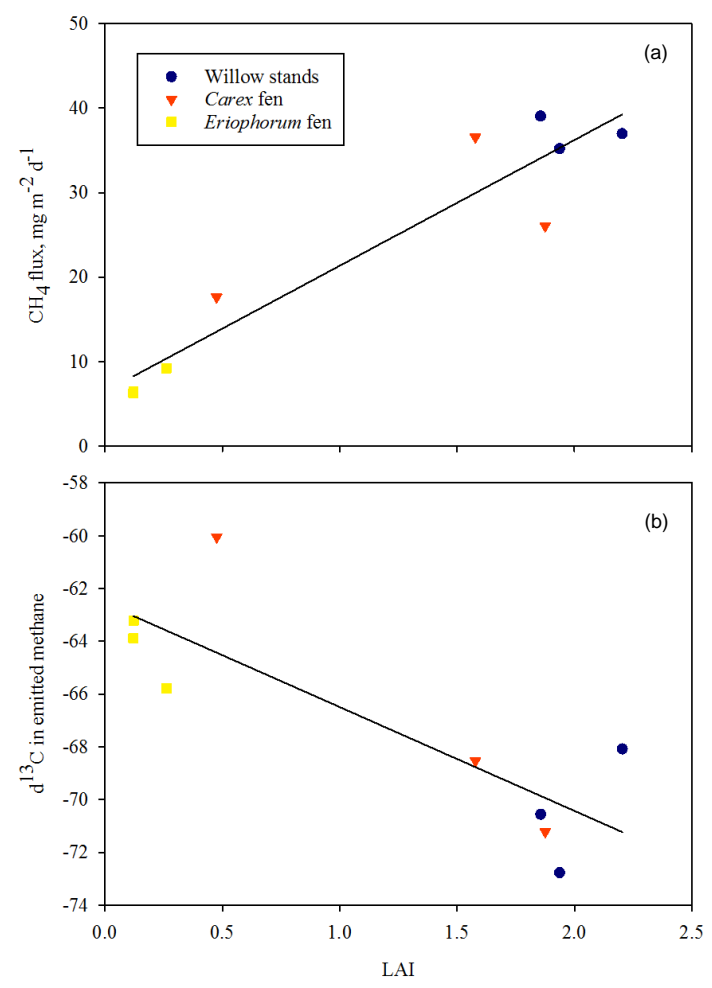

Figure 4. Correlation between cumulative seasonal $\mathrm{CH}_{4}$ fluxes with (a) mean vascular LAI, (b) $\delta^{13} \mathrm{C}$ of $\mathrm{CH}_{4}$ flux recorded in different wetland LCTs during the 2008 growing season.

land types were $11 \pm 4.5,37 \pm 17$, and $53 \pm 8 \mathrm{~g} \mathrm{CH}_{4} \mathrm{~m}^{-2}$, respectively (the standard deviations indicate the flux variability associated with replicate measurements). At willow and Carex fen sites, the floating Sphagnum mat followed the fluctuations in the ground water level. This dampened the amplitude of the water table level variation relative to the moss surface. While the absolute amplitude of the water table level at the fen sites in 2008 was $23 \mathrm{~cm}$, this was reduced to about $10 \mathrm{~cm}$ relative to the moss surface as a result of the surface adjustment. Consequently, the fen sites remained submerged $5-10 \mathrm{~cm}$ below the water level even during the driest part of the growing season in July 2008. The willow LCT did not have a floating moss layer but the mean water table was still maintained close to the moss surface. The $\mathrm{CH}_{4}$ fluxes from these sites showed a strong exponential dependence on soil temperature at the individual plot level. Moreover, a strong exponential relationship between $\mathrm{CH}_{4}$ flux and soil temperature was also corroborated by EC measurements made on the landscape level (Fig. 5). The drier peatland habitats - the tundra bog and bare peat circles - were smaller $\mathrm{CH}_{4}$ sources $\left(0.2 \pm 0.2\right.$ and $0.7 \pm 1.1 \mathrm{~g} \mathrm{CH}_{4} \mathrm{~m}^{-2} \mathrm{yr}^{-1}$, respectively). The upland tundra types were at times small sinks for atmospheric methane during the season. When accumulated over the entire season, they were close to being neutral, with the $\mathrm{CH}_{4}$ emissions ranging from -0.03 to $0.13 \mathrm{~g} \mathrm{CH}_{4} \mathrm{~m}^{-2}$. 
The annual $\mathrm{CH}_{4}$ emissions from the thermokarst lakes varied from 2.1 to $5.3 \mathrm{~g} \mathrm{CH}_{4} \mathrm{~m}^{-2}$ (mean $4.2 \mathrm{~g} \mathrm{CH}_{4} \mathrm{~m}^{-2}$ ), and thus were lower than for wetland sites (Fig. 3b). The magnitude of total $\mathrm{CH}_{4}$ emissions as well as the importance of diffusion vs. ebullition pathways varied strongly among the lakes. The contribution of the ebullitive flux ranged from 5 to $94 \%$ and was the highest in the biggest of the lakes with the most intensive thermokarst processes occurring. The highest diffusive flux was observed in the smallest lake with the least open water area. The seasonal mean $\mathrm{CH}_{4}$ concentration in the surface water was $0.3-3.7 \mu \mathrm{mol} \mathrm{L}^{-1}$ in 2007 and 0.4 $8.0 \mu \mathrm{mol} \mathrm{L}^{-1}$ in 2008 .

\subsection{Isotopic signature of $\mathrm{C}-\mathrm{CH}_{4}$ in emission and porewater}

The $\delta^{13} \mathrm{C}$ of $\mathrm{CH}_{4}$ flux did not show much variability among the wetland types, years, or sampling dates (Table 2, Fig. 6). The bulk average $\pm \mathrm{SD}$ of $\delta^{13} \mathrm{C}$ in $\mathrm{CH}_{4}$ emitted across peatland types and years was $-68.2 \pm 2.0 \%$. During the June sampling in 2008, the $\mathrm{CH}_{4}$ released from Eriophorum fen was remarkably heavier than during the other samplings or at other wetland types, which resulted in a high mean annual $\delta^{13} \mathrm{C}-\mathrm{CH}_{4}$ value. Methane emitted from wetlands was lighter $\left(\delta^{13} \mathrm{C}\right.$ more negative) than the porewater $\mathrm{CH}_{4}$ at 5 and $30 \mathrm{~cm}$ depth (Fig. 6). In most of the cases, $\delta^{13} \mathrm{C}$ of porewater $\mathrm{CH}_{4}$ at $5 \mathrm{~cm}(-52.3 \pm 6.6 \%$ o was heavier than that at $30 \mathrm{~cm}(-60.7 \pm 2.8 \%$ ). The more detailed profile samplings in 2008 revealed an overall trend of decreasing $\delta^{13} \mathrm{C}$ values with depth (Fig. 7). Porewater $\mathrm{CH}_{4}$ in the rhizosphere (0$20 \mathrm{~cm}$ ) was enriched with ${ }^{13} \mathrm{C}$ compared to deeper depths. Also, $\mathrm{CH}_{4}$ released to the atmosphere was lighter than that at any depth in the peat profile, except for the June sampling at Eriophorum fen. A negative linear correlation was found between $\delta^{13} \mathrm{C}$ in $\mathrm{CH}_{4}$ emission and vascular LAI across the wetland plots (Fig. 4, the higher the LAI, the lighter the $\mathrm{CH}_{4}$ emitted; $P<0.0001)$.

\subsection{Landscape-scale and regional $\mathrm{CH}_{4}$ balance}

The fluxes of various land cover types were spatially extrapolated over the EC footprint area and further over the whole study region of $98.6 \mathrm{~km}^{2}$ using the data on the land cover classification. When the plot-scale measurements were scaled up to the EC footprint area, the $\mathrm{CH}_{4}$ flux estimate $\left(3.7 \mathrm{~g} \mathrm{CH}_{4} \mathrm{~m}^{-2}\right)$ obtained was larger than the estimate by the EC technique $\left(2.4 \mathrm{~g} \mathrm{CH}_{4} \mathrm{~m}^{-2}\right.$ for the whole EC measuring campaign, Fig. 3c). An LAI map produced for the area based on the QuickBird image (see Marushchak et al., 2013) showed that the fen plots selected for the chamber measurements had on average higher LAI (1.2) than the fens in the region (0.7). If the linear relationship between $\mathrm{CH}_{4}$ flux and LAI presented in Fig. 4 is used to correct the $\mathrm{CH}_{4}$ fluxes from fens to account for the lower LAI in the landscape, the $\mathrm{CH}_{4}$

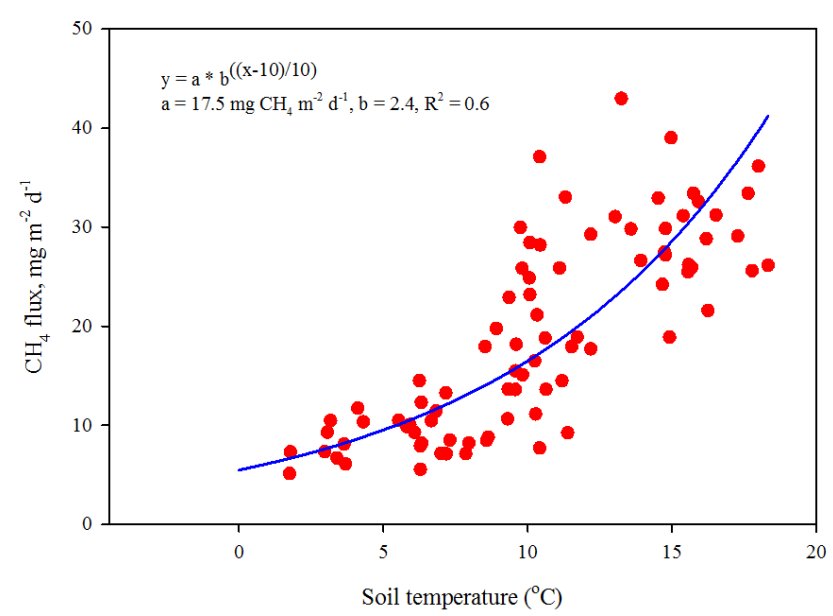

Figure 5. Dependence of $\mathrm{CH}_{4}$ flux measured using EC technique from June until early October at fen surfaces on soil temperature. The solid line represents the $\mathrm{Q}_{10}$ function fitted to the data using a nonlinear least-squares fit ( $x$ is soil temperature, $y$ is daily mean methane flux, $a$ represents the base methane flux rate and $b$ is the $\mathrm{Q}_{10}$ coefficient). The statistics generated from the regression analysis are also presented in the graph.

estimate was reduced to $2.8 \mathrm{~g} \mathrm{CH}_{4} \mathrm{~m}^{-2}$. This is close to the estimate based on EC measurements (Table 3).

The regional $\mathrm{CH}_{4}$ emission, without LAI correction for fen fluxes, was $5.6 \mathrm{~g} \mathrm{CH}_{4} \mathrm{~m}^{-2}$ for the $\mathrm{EC}$ measurement period from May through September and $6.7 \mathrm{~g} \mathrm{CH}_{4} \mathrm{~m}^{-2}$ for the whole year. Contribution of the non-growing season to this annual $\mathrm{CH}_{4}$ flux was $30 \%$. The higher emission compared to the EC footprint area can be explained by higher coverage of wetlands in the whole study region (willow coverage $8.7 \%$ vs. $1.6 \%)$. In the EC footprint area there were more tundra bog $(39 \%)$, fen $(10 \%)$, and lakes $(9 \%)$ and less tundra heath $(41 \%)$ and willows (2\%) than in the whole QuickBird area.

\section{Discussion}

In comparison with other studies of the Russian Arctic tundra, the landscape-scale $\mathrm{CH}_{4}$ emissions estimated in the present study are relatively low. Methane flux values presented here are comparable to those measured during June to mid-September in the Lena River Delta (Sachs et al., 2008; Wille et al., 2008). A seasonal (May-September) emission of $2.4 \mathrm{~g} \mathrm{CH}_{4} \mathrm{~m}^{-2}$ as measured by EC technique is less than what has been reported for northeastern Siberia - e.g. Cor-

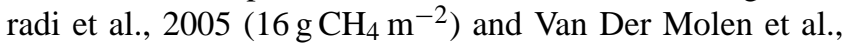
$2007\left(4 \mathrm{~g} \mathrm{CH}_{4} \mathrm{~m}^{-2}\right)$. The emissions reported in this study are also lower compared to the work of Jackowicz-Korczyński et al. (2010) in subarctic Scandinavia $\left(25 \mathrm{~g} \mathrm{CH}_{4} \mathrm{~m}^{-2}\right)$. Emission rates reported here are similar to the rates measured by Friborg (2003) during a summer season at a high Arctic fen site in NE Greenland. Overall, $\mathrm{CH}_{4}$ emissions from this site 
Table 2. Isotopic signature $\left({ }^{13} \mathrm{C}\right)$ of $\delta^{13} \mathrm{C}$ in $\mathrm{CH}_{4}$ emission of various tundra wetland types and magnitude of $\mathrm{CH}_{4}$ flux during isotope sampling. Data are growing season means $\pm \mathrm{SD}, n=3$.

\begin{tabular}{lrrrr}
\hline & & Carex fen & Eriophorum fen & Willow stand \\
\hline$\delta^{13} \mathrm{C}^{\text {in } \mathrm{CH}_{4} \text { flux }}$ & 2007 & $-66.8 \pm 2.5$ & $-70.8 \pm 1.1$ & $-70.4 \pm 2.6$ \\
& 2008 & $-66.6 \pm 5.8$ & $-64.3 \pm 1.3$ & $-70.5 \pm 2.3$ \\
$\mathrm{CH}_{4}$ flux, $\mathrm{mg} \mathrm{CH}_{4} \mathrm{~m}^{-2} \mathrm{~d}^{-1}$ & 2007 & $10.1 \pm 1.0$ & $3.4 \pm 2.8$ & $9.1 \pm 2.4$ \\
& 2008 & $6.8 \pm 1.3$ & $1.5 \pm 0.5$ & $8.7 \pm 0.2$ \\
\hline
\end{tabular}

Table 3. Methane balance of the eddy covariance (EC) tower footprint area and the whole study region of $98.6 \mathrm{~km}^{2}$ based on EC and areaintegrated plot-scale measurements. For the EC tower footprint area, chamber fluxes were corrected to account for the higher LAI on fen measurement plots (see text for more details on why such a correction was necessary).

\begin{tabular}{lll}
\hline $\mathrm{CH}_{4}$ balance, $\mathrm{g} \mathrm{CH}_{4} \mathrm{~m}^{-2}$ & $\begin{array}{l}\text { EC measuring campaign } \\
2008 \text { (days 139-279) }\end{array}$ & $\begin{array}{l}\text { Annual } \\
\text { (days 280/2007-279/2008) }\end{array}$ \\
\hline EC footprint area & & \\
\hline EC & 2.4 & $\begin{array}{l}\text { not determined } \\
\text { Plot-scale measurements, with LAI correction }\end{array}$ \\
Plot-scale measurements, without LAI correction & $3.8 \pm 1.6$ & $4.4 \pm 2.1$ \\
\hline Study region of 98.6 km & & \\
\hline Plot-scale measurements, without LAI correction & $5.6 \pm 1.3$ & $6.7 \pm 1.8$ \\
\hline
\end{tabular}

are relatively low, owing to a low coverage of high-emitting wetlands (less than 20\%). Nevertheless, it is evident from our chamber measurements that the wet parts of the tundra ecosystem in the Seida area emit $\mathrm{CH}_{4}$ at a rate equivalent or higher than what has been reported for similar tundra habitats in Russia (e.g. Heikkinen et al., 2004).

The area-integrated chamber measurements presented here show higher fluxes than those measured by the EC technique (Table 3 ). This could be attributed to the disparity in the distribution of different land cover types within and outside the EC tower footprint and to the variability associated with the fluxes among various surface types as measured by the chambers. The high variability among the surface types accounts for the difference in the estimates by the two techniques. For example, the fen plots measured with chambers had higher LAI than the fens in the region in general. Based on the relationship between $\mathrm{CH}_{4}$ flux and LAI, when we corrected the chamber $\mathrm{CH}_{4}$ flux estimate for such a LAI variation, the $\mathrm{CH}_{4}$ estimates based on the two independent methods agreed with each other. Without this correction, the chamber-based seasonal $\mathrm{CH}_{4}$ flux was higher than the ECbased estimate $\left(2.4 \mathrm{~g} \mathrm{CH}_{4} \mathrm{~m}^{-2}\right)$.

To characterize the $\mathrm{CH}_{4}$ released from the fens and willow stands, we measured the $\delta^{13} \mathrm{C}$ values of $\mathrm{CH}_{4}$ in porewater and surface emissions. The overall mean $\delta^{13} \mathrm{C}$ value of $\mathrm{CH}_{4}$ released to the atmosphere was $-68.2 \%$. This value is within the range of values reported for wetlands from the Arctic including Siberia (McCalley et al., 2014; Sriskantharajah et al., 2012). The $\delta^{13} \mathrm{C}$ value of $\mathrm{CH}_{4}$ from wetlands worldwide is $-59 \pm 6 \%$ (McCalley et al., 2014). Generally, the isotope signal of $\mathrm{CH}_{4}$ from wetlands appears to be rather constant and sufficiently distinct from other large sources, e.g. biomass burning (Monteil et al., 2011), supporting the use of isotopes to better constrain sources and sinks of atmospheric $\mathrm{CH}_{4}$ by inverse modelling.

We have shown here that the $\mathrm{CH}_{4}$ emitted from the surface is substantially lighter than the porewater methane. The ${ }^{13} \mathrm{C}$ depletion in the $\mathrm{CH}_{4}$ emission combined with rhizospheric enrichment of ${ }^{13} \mathrm{C}-\mathrm{CH}_{4}$ suggests that a large part of the emitted $\mathrm{CH}_{4}$ is transported from peat to the atmosphere via plant aerenchyma, the gas exchange system of aquatic plants. Diffusion through air-filled aerenchyma causes fractionation against the heavier ${ }^{13} \mathrm{C}$-isotope, thus depleting the $\delta^{13} \mathrm{C}$ of $\mathrm{CH}_{4}$ released from plants to the atmosphere (Chanton et al., 2005). This in turn leaves rhizospheric $\mathrm{CH}_{4}$ enriched with $\delta^{13} \mathrm{C}$. Accordingly, we observed less negative $\delta^{13} \mathrm{C}$ of porewater $\mathrm{CH}_{4}$ in the rhizosphere than at greater depths, where it presumably was unaffected by fractionation due to plant-mediated transport. Besides passive plantmediated transport, another process that causes $\delta^{13} \mathrm{C}$ depletion of $\mathrm{CH}_{4}$ emissions relative to porewater $\mathrm{CH}_{4}$ is $\mathrm{CH}_{4}$ oxidation during diffusion through the peat column. However, the importance of oxidation is likely minor in these wetlands with such high water tables. Similar observations of depleted $\mathrm{CH}_{4}$ in surface emissions compared to porewater were made by others (Popp et al., 1999). It has been generally argued that plant-mediated transport accounts for a large share of $\mathrm{CH}_{4}$ emissions in wetlands inhabited by vascular 

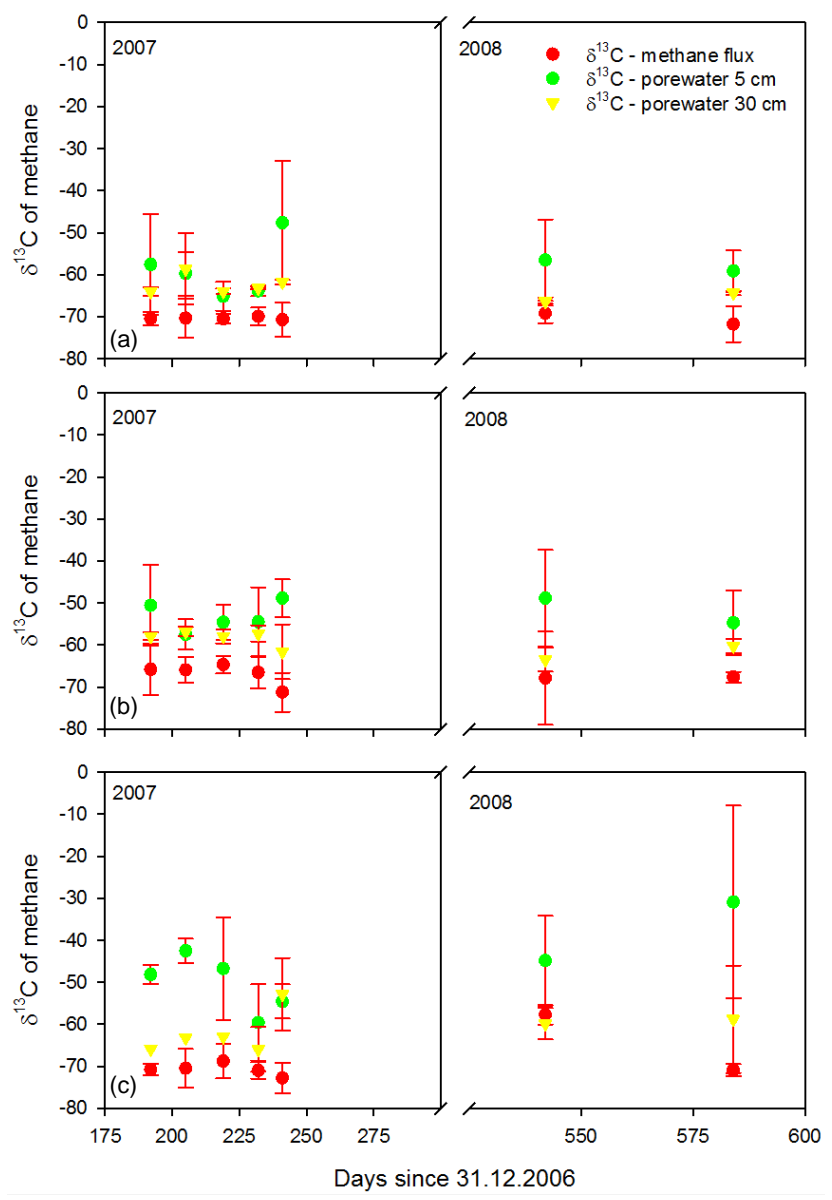

Figure 6. Mean and standard deviations in $\delta^{13} \mathrm{C}$ of emitted $\mathrm{CH}_{4}$ (red) and of $\mathrm{CH}_{4}$ contained in porewater samples collected from $5 \mathrm{~cm}$ (green) and $30 \mathrm{~cm}$ depths (yellow) of wetlands at the Seida site during 2007 and 2008 growing seasons from (a) willow stands, (b) Carex fens and (c) Eriophorum fens.

plants (Kutzbach et al., 2004; Riley et al., 2011; Van Der Nat et al., 1998).

The assumption that plants play a role in the release of $\mathrm{CH}_{4}$ from these sites is further supported by the negative correlation between $\delta^{13} \mathrm{C}$ of emitted $\mathrm{CH}_{4}$ and LAI. The depletion of ${ }^{13} \mathrm{C}_{-} \mathrm{CH}_{4}$ with increasing LAI cannot be driven by the influence of plant-derived $\mathrm{C}$ supply for methanogens (Riley et al., 2011). On the contrary, this would have lead to a positive correlation: the acetate fermentation pathway that relies on input of labile $\mathrm{C}$ compounds produces more enriched $\mathrm{CH}_{4}$ than $\mathrm{CO}_{2}$ reduction (Whiticar, 1999). The observation that plants mediate $\mathrm{CH}_{4}$ release is important in the context of climate change. This implies that a significant part of the $\mathrm{CH}_{4}$ produced in the soil profile bypasses the oxic soil zones, thus confounding the effect of water table variations.

Temperature records from the nearby Vorkuta station ( $75 \mathrm{~km}$ north of the field site) show that the average air temperature in the region rose by $0.9^{\circ} \mathrm{C}$ from $1980-1999$ to

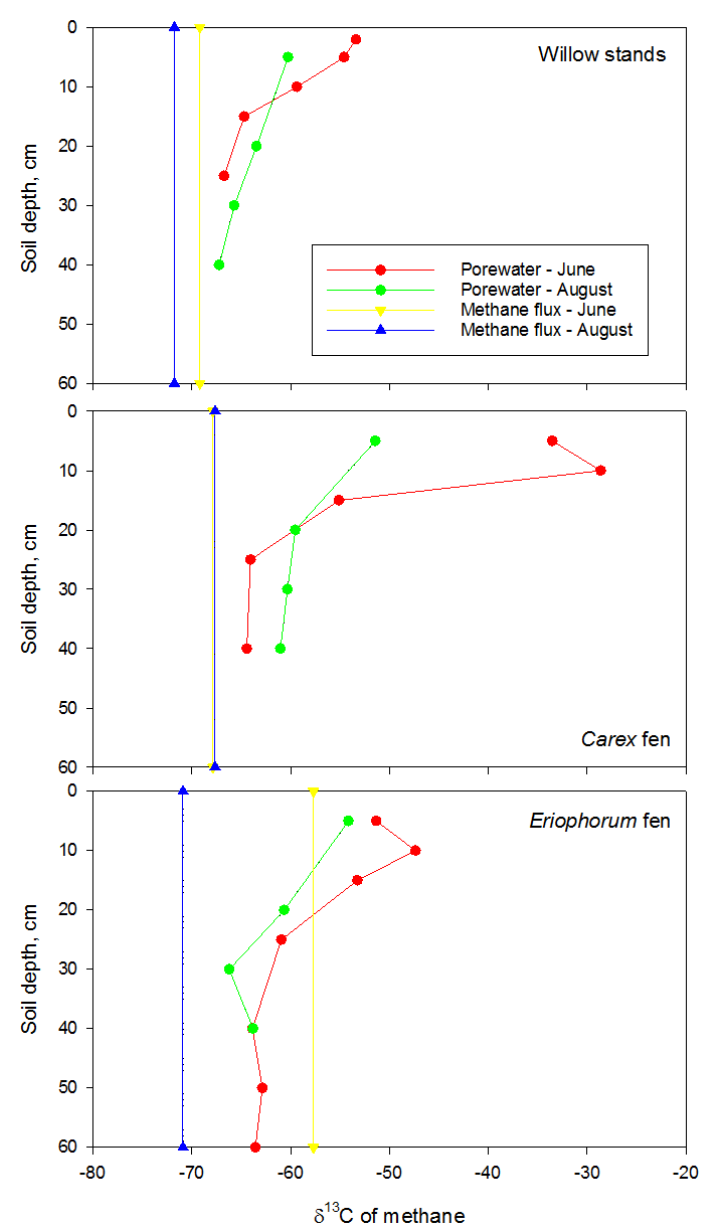

Figure 7. Profiles of porewater $\delta^{13} \mathrm{C}-\mathrm{CH}_{4}$ of wetlands at the Seida site in June (red) and August (green) 2008. Yellow and blue vertical lines represent $\delta^{13} \mathrm{C}$ of $\mathrm{CH}_{4}$ emitted during June and August, respectively.

2000-2008 (P. Kuhry, personal communication, 2010). A climate scenario for the northern part of the Komi Republic, the region within which the study site is situated, was developed as part of the CARBO-North project using the IPCC-SRES emission scenario A1B, which predicts a global warming of $2.8^{\circ} \mathrm{C}$ by 2100 relative to today (Stendel et al., 2011). For the northern part of the Komi Republic, a temperature increase of nearly $7^{\circ} \mathrm{C}$ relative to the average over the period 1980 1999 is predicted by 2100 . The clear $\mathrm{Q}_{1} 0$-type temperature response of $\mathrm{CH}_{4}$ flux found in this study (Fig. 5) suggests that warming of this magnitude could lead to a substantial increase of $\mathrm{CH}_{4}$ emission. A crucial point in the assumption is that the water table remains within a range favourable for $\mathrm{CH}_{4}$ production despite the increases in evapotranspiration, which can be expected due to the higher temperatures. The floating peatland surface in fens typical of this area adjusts to fluctuations in the water table. This implies that the fen types might remain water-logged, even if other tundra habitats would get drier. Additionally, the isotope data suggest 
that $\mathrm{CH}_{4}$ is released largely via plant aerenchyma thereby escaping its oxidation, implying relatively minor effects of water table fluctuations. Moreover, the growth of willow stands in the study area has been reported to be higher owing to warmer temperatures (Forbes et al., 2010). Enhanced willow stand productivity may further lead to increased $\mathrm{CH}_{4}$ emissions, also evidenced by the fact that plants control the net $\mathrm{CH}_{4}$ release. Based on the positive correlation between LAI and $\mathrm{CH}_{4}$ flux, we estimate that a $50 \%$ increase in the LAI would favour enhanced release of $\mathrm{CH}_{4}$ to the extent of nearly $35 \%$ from tundra wetlands in the study region.

While less uncertainty is associated with the direct effects of temperature increase on the methanogenic processes, a high degree of uncertainty does exist with respect to consequences of temperature increases on the geomorphological changes of the studied tundra landscape and their possible impact on vegetation. In addition to the direct enhancement of $\mathrm{CH}_{4}$ fluxes by higher temperatures, warming of $6.1^{\circ} \mathrm{C}$ by 2100 relative to the present day will evidently cause thawing of permafrost and result in landscape changes in the study region. Our measurements of active layer thickness over the season reveal that the seasonal active layer is deepest in the wettest (low-lying) parts of the tundra, which are characterized by lakes, fens, and willow wetlands. A possible consequence of the predicted warming could be that these wetland cover types become more prevalent in the future. Based on our results, willow stands and fen sites are the strongest emitters of $\mathrm{CH}_{4}$. Any landscape change leading to the formation and expansion of such wetland types owing to permafrost thaw would further increase $\mathrm{CH}_{4}$ escape, thus providing a strong positive feedback to climate change in the region.

\section{Concluding remarks}

Arctic tundra ecosystems are among the world's fastest warming biomes. These ecosystems, underlain by permafrost, are extremely vulnerable to the impacts of anthropogenic climate change. They have been a huge store for organic $\mathrm{C}$ since the last glaciation in the area. The current warming Arctic trend poses a threat to these ecosystems as their soil temperature is likely to rise above $0^{\circ} \mathrm{C}$ leading subsequently to the thawing of the underlying permafrost. While the fact that these ecosystems are fast undergoing changes has been established with a fair degree of certainty based on field data, how these ecosystems will respond to the future climate is still uncertain. Therefore, with a view to understanding the future ecosystem responses better, regional studies aiming at a proper characterization of the atmospherebiosphere greenhouse gas (GHG) exchange in the Arctic have been launched. To that end, the work presented in this paper serves to provide the much-needed seasonal and annual methane flux estimates from Northeast European Russia, a region not yet well represented in the Arctic studies. Flux data on other GHGs $\left(\mathrm{CO}_{2}\right.$ and $\left.\mathrm{N}_{2} \mathrm{O}\right)$ from this study site have already been reported in earlier publications (Repo et al., 2009; Marushchak et al., 2011, 2013).

Owing to the spatially heterogeneous nature of the studied ecosystem (Virtanen and Ek, 2014), this study segregated the site into several major land cover types employing a fine-scale land cover classification scheme. Chamber techniques were used to measure $\mathrm{CH}_{4}$ fluxes during 2007 and 2008 growing seasons from replicate plots on 10 different LCTs. These data were useful in characterizing the inherent variability in methane $\mathrm{CH}_{4}$ flux at the studied site. To complement these plot-scale measurements, the EC technique was also used to characterize this ecosystem's $\mathrm{CH}_{4}$ source strength. Employing empirical modelling and vascular leaf area data, the up-scaled plot-scale data agreed well with the seasonal $\mathrm{CH}_{4}$ flux estimates obtained using the EC technique. Soil temperature, water table level, and leaf area were found to be the major factors controlling $\mathrm{CH}_{4}$ release to the atmosphere. Growing season $\delta^{13} \mathrm{C}_{-} \mathrm{CH}_{4}$ isotopic analyses confirmed the important role of plants in transferring methane to the atmosphere. The data and process-level information generated in this study are useful in the biogeochemical modelling of $\mathrm{C}$ and $\mathrm{N}$ dynamics in Arctic ecosystems.

Acknowledgements. This research was funded by the Danish Council for Independent Research Natural Sciences (FNU) (Reference number: 645-06-0493) and the EU Sixth Framework Programme Global Change and Ecosystems (CARBO-North, project contract number 036993). Petr Ievlev, Simo Jokinen, Igor Marushchak, Aleksander Novakovsky, Irina Samarina, Vladimir Shchanov, and Tatiana Trubnikova are acknowledged for the contribution to determination of plot-scale fluxes and Thomas Grelle, Daniel Grube Pedersen Rasmus Jensen, and Anders Bjørk for their technical support of the EC measurements. M. E. Marushchak received personal funding from the Finnish Graduate School of Forest Sciences. Maarit Liimatainen received funding from Olvi Foundation for her contribution in this work. Further, we thank P. Kuhry and M. Stendel for their contribution to the IPCC model scenarios for the Komi region.

Edited by: T. R. Christensen

\section{References}

Anisimov, O. A.: Potential feedback of thawing permafrost to the global climate system through methane emission, Environ. Res. Lett., 2, 045016, doi:10.1088/1748-9326/2/4/045016, 2007.

Aubinet, M., Grelle, A., Ibrom, A., Rannik, Ü., Moncrieff, J., Foken, T., Kowalski, A. S., Martin, P. H., Berbigier, P., Bernhofer, C., Clement, R., Elbers, J., Granier, A., Grünwald, T., Morgenstern, K., Pilegaard, K., Rebmann, C., Snijders, W., Valentini, R., and Vesala, T.: Estimates of the Annual Net Carbon and Water Exchange of Forests: The EUROFLUX Methodology, 30, 113175, doi:10.1016/s0065-2504(08)60018-5, 1999.

Biasi, C., Jokinen, S., Marushchak, M. E., Hämäläinen, K., Trubnikova, T., Oinonen, M., and Martikainen, P. J.: Microbial 
Respiration in Arctic Upland and Peat Soils as a Source of Atmospheric Carbon Dioxide, Ecosystems, 17, 112-126, doi:10.1007/s10021-013-9710-z, 2013.

Chanton, J. P.: The effect of gas transport on the isotope signature of methane in wetlands, Org. Geochem., 36, 753-768, doi:10.1016/j.orggeochem.2004.10.007, 2005.

Chanton, J. P., Chaser, L., Glaser, P., and Siegel, D.: Carbon and hydrogen isotopic effects in microbial methane from terrestrial environments, in Stable Isotopes and Biosphere-Atmosphere Interactions, in, Physiological Ecology Series Elsevier, Amsterdam, 85-105, 2005.

Christensen, T. R.: Thawing sub-arctic permafrost: Effects on vegetation and methane emissions, Geophys. Res. Lett., 31, L04501, doi:10.1029/2003g1018680, 2004.

Corradi, C., Kolle, O., Walter, K., Zimov, S. A., and Schulze, E. D.: Carbon dioxide and methane exchange of a north-east Siberian tussock tundra, Glob. Change Biol., 11, 1910-1925, doi:10.1111/j.1365-2486.2005.01023.x, 2005.

Dlugokencky, E. J., Nisbet, E. G., Fisher, R., and Lowry, D.: Global atmospheric methane: budget, changes and dangers, Philos. T. Roy. Soc. Ai, 369, 2058-2072, doi:10.1098/rsta.2010.0341, 2011.

Dorodnikov, M., Marushchak, M., Biasi, C., and Wilmking, M.: Effect of microtopography on isotopic compoition of methane in porewater and efflux at a boreal peatland, Boreal Environ. Res., 18, 269-279, 2013.

Foken, T., Göckede, M., Mauder, M., Mahrt, L., Amiro, B. D., and Munger, J. W.: Post-field data quality control, in: Handbook of Mcrometeorology: A Guide for Surface Flux Measurement and Analysis, Atmospheric and Oceanographic Library Series, 29, edited by: Lee, X., Massman, W., and Law, B., Kluwer, Dordrecht, 181-208, 2004.

Forbes, B. C., Fauria, M. M., and Zetterberg, P.: Russian Arctic warming and 'greening' are closely tracked by tundra shrub willows, Glob. Change Biol., 16, 1542-1554, doi:10.1111/j.13652486.2009.02047.x, 2010.

Friborg, T.: Siberian wetlands: Where a sink is a source, Geophys. Res. Lett., 30, 2129, doi:10.1029/2003g1017797, 2003.

Heikkinen, J. E. P., Virtanen, T., Huttunen, J. T., Elsakov, V., and Martikainen, P. J.: Carbon balance in East European tundra, Global Biogeochem. Cy., 18, GB1023, doi:10.1029/2003gb002054, 2004.

Hugelius, G., Virtanen, T., Kaverin, D., Pastukhov, A., Rivkin, F., Marchenko, S., Romanovsky, V., and Kuhry, P.: High-resolution mapping of ecosystem carbon storage and potential effects of permafrost thaw in periglacial terrain, European Russian Arctic, J. Geophys. Res., 116, G03024, doi:10.1029/2010jg001606, 2011 .

IPCC: Climate Change 2014: Mitigation of Climate Change. Contribution of Working Group III to the Fifth Assessment Report of the Intergovernmental Panel on Climate Change, Cambridge, United Kingdom and New York, NY, USA, 2014.

Jackowicz-Korczyński, M., Christensen, T. R., Bäckstrand, K., Crill, P., Friborg, T., Mastepanov, M., and Ström, L.: Annual cycle of methane emission from a subarctic peatland, J. Geophys. Res., 115, Journal of Geophysical Research, doi:10.1029/2008jg000913, 2010.

Johansson, T., Malmer, N., Crill, P. M., Friborg, T., ÅKerman, J. H., Mastepanov, M., and Christensen, T. R.: Decadal veg- etation changes in a northern peatland, greenhouse gas fluxes and net radiative forcing, Glob. Change Biol., 12, 2352-2369, doi:10.1111/j.1365-2486.2006.01267.x, 2006.

Kiepe, I., Friborg, T., Herbst, M., Johansson, T., and Soegaard, H.: Modeling Canopy $\mathrm{CO}_{2}$ Exchange in the European Russian Arctic, Arct. Antarct. Alp. Res., 45, 50-63, doi:10.1657/1938-424645.1.50, 2013.

Kutzbach, L., Wagner, D., and Pfeiffer, E.: Effect of microrelief and vegetation on methane emission from wet polygonal tundra, Lena Delta, Northern Siberia, Biogeochemistry, 69, 341362, 2004.

Liss, P. S., and Slater, P. G.: Flux of Gases across the Air-Sea Interface, Nature, 247, 181-184, 1974.

Maljanen, M., Liikanen, A., Silvola, J., and Martikainen, P. J.: Measuring $\mathrm{N}_{2} \mathrm{O}$ emissions from organic soils by closed chamber or soil/snow $\mathrm{N}_{2} \mathrm{O}$ gradient methods, Eur. J. Soil Sci., 54, 625-631, doi:10.1046/j.1365-2389.2003.00531.x, 2003.

Marushchak, M. E., Pitkämäki, A., Koponen, H., Biasi, C., Seppälä, M., and Martikainen, P. J.: Hot spots for nitrous oxide emissions found in different types of permafrost peatlands, Glob. Change Biol., 17, 2601-2614, doi:10.1111/j.1365-2486.2011.02442.x, 2011.

Marushchak, M. E., Kiepe, I., Biasi, C., Elsakov, V., Friborg, T., Johansson, T., Soegaard, H., Virtanen, T., and Martikainen, P. J.: Carbon dioxide balance of subarctic tundra from plot to regional scales, Biogeosciences, 10, 437-452, doi:10.5194/bg-10437-2013, 2013.

Mastepanov, M., Sigsgaard, C., Dlugokencky, E. J., Houweling, S., Strom, L., Tamstorf, M. P., and Christensen, T. R.: Large tundra methane burst during onset of freezing, Nature, 456, 628-630, doi:10.1038/nature07464, 2008.

McCalley, C. K., Woodcroft, B. J., Hodgkins, S. B., Wehr, R. A., Kim, E. H., Mondav, R., Crill, P. M., Chanton, J. P., Rich, V. I., Tyson, G. W., and Saleska, S. R.: Methane dynamics regulated by microbial community response to permafrost thaw, Nature, 514, 478-481, doi:10.1038/nature13798, 2014.

McGuire, A. D., Christensen, T. R., Hayes, D., Heroult, A., Euskirchen, E., Kimball, J. S., Koven, C., Lafleur, P., Miller, P. A., Oechel, W., Peylin, P., Williams, M., and Yi, Y.: An assessment of the carbon balance of Arctic tundra: comparisons among observations, process models, and atmospheric inversions, Biogeosciences, 9, 3185-3204, doi:10.5194/bg-9-3185-2012, 2012.

Merbold, L., Steinlin, C., and Hagedorn, F.: Winter greenhouse gas fluxes $\left(\mathrm{CO}_{2}, \mathrm{CH}_{4}\right.$ and $\left.\mathrm{N}_{2} \mathrm{O}\right)$ from a subalpine grassland, Biogeosciences, 10, 3185-3203, doi:10.5194/bg-10-3185-2013, 2013.

Monteil, G., Houweling, S., Dlugockenky, E. J., Maenhout, G., Vaughn, B. H., White, J. W. C., and Rockmann, T.: Interpreting methane variations in the past two decades using measurements of $\mathrm{CH}_{4}$ mixing ratio and isotopic composition, Atmos. Chem. Phys., 11, 9141-9153, doi:10.5194/acp-11-9141-2011, 2011.

Mörsky, S. K., Haapala, J. K., Rinnan, R., Tiiva, P., Saarnio, S., Silvola, J., Holopainen, T., and Martikainen, P. J.: Long-term ozone effects on vegetation, microbial community and methane dynamics of boreal peatland microcosms in open-field conditions, Glob. Change Biol., 14, 1891-1903, doi:10.1111/j.13652486.2008.01615.x, 2008.

Parmentier, F. J. W., van Huissteden, J., Kip, N., Op den Camp, H. J. M., Jetten, M. S. M., Maximov, T. C., and Dolman, A. J.: The role of endophytic methane-oxidizing bacteria in submerged Sphag- 
num in determining methane emissions of Northeastern Siberian tundra, Biogeosciences, 8, 1267-1278, doi:10.5194/bg-8-12672011, 2011.

Pataki, D. E., Ehleringer, J. R., Flanagan, L. B., Yakir, D., Bowling, D. R., Still, C. J., Buchmann, N., Kaplan, J. O., and Berry, J. A.: The application and interpretation of Keeling plots in terrestrial carbon cycle research, Global Biogeochem. Cy., 17, 1022, doi:10.1029/2001gb001850, 2003.

Popp, T. J., Chanton, J. P., Whiting, G. J., and Grant, N.: Methane stable isotope distribution at aCarexdominated fen in north central Alberta, Global Biogeochem. Cy., 13, 1063-1077, doi:10.1029/1999gb900060, 1999.

Post, E., Forchhammer, M. C., Bret-Harte, M. S., Callaghan, T. V., Christensen, T. R., Elberling, B., Fox, A. D., Gilg, O., Hik, D. S., Høye, T. T., Ims, R. A., Jeppesen, E., Klein, D. R., Madsen, J., McGuire, A. D., Rysgaard, S., Schindler, D. E., Stirling, I., Tamstorf, M. P., Tyler, N. J. C., van der Wal, R., Welker, J., Wookey, P. A., Schmidt, N. M., and Aastrup, P.: Ecological Dynamics Across the Arctic Associated with Recent Climate Change, Science, 325, 1355-1358, doi:10.1126/science.1173113, 2009.

Repo, M. E., Huttunen, J. T., Naumov, A. V., Chichulin, A. V., Lapshina, E. D., Bleuten, W., and Martikainen, P. J.: Release of $\mathrm{CO}_{2}$ and $\mathrm{CH}_{4}$ from small wetland lakes in western Siberia, Tellus B, 59, 788-796, doi:10.1111/j.1600-0889.2007.00301.x, 2007.

Repo, M. E., Susiluoto, S., Lind, S. E., Jokinen, S., Elsakov, V., Biasi, C., Virtanen, T., and Martikainen, P. J.: Large $\mathrm{N}_{2} \mathrm{O}$ emissions from cryoturbated peat soil in tundra, Nat. Geosci., 2, 189-192, doi:10.1038/ngeo434, 2009.

Riley, W. J., Subin, Z. M., Lawrence, D. M., Swenson, S. C., Torn, M. S., Meng, L., Mahowald, N. M., and Hess, P.: Barriers to predicting changes in global terrestrial methane fluxes: analyses using CLM4Me, a methane biogeochemistry model integrated in CESM, Biogeosciences, 8, 1925-1953, doi:10.5194/bg-8-19252011, 2011.

Romanovsky, V. E., Smith, S. L., and Christiansen, H. H.: Permafrost thermal state in the polar Northern Hemisphere during the international polar year 2007-2009: a synthesis, Permafrost Periglac., 21, 106-116, doi:10.1002/ppp.689, 2010.

Sachs, T., Wille, C., Boike, J., and Kutzbach, L.: Environmental controls on ecosystem-scale $\mathrm{CH}_{4}$ emission from polygonal tundra in the Lena River Delta, Siberia, J. Geophys. Res., 113, 30963110, doi:10.1029/2007jg000505, 2008.

Sapart, C. J., Martinerie, P., Witrant, E., Chappellaz, J., van de Wal, R. S. W., Sperlich, P., van der Veen, C., Bernard, S., Sturges, W. T., Blunier, T., Schwander, J., Etheridge, D., and Röckmann, T.: Can the carbon isotopic composition of methane be reconstructed from multi-site firn air measurements?, Atmos. Chem. Phys., 13, 6993-7005, doi:10.5194/acp-13-6993-2013, 2013.
Soegaard, H., Nordstroem, C., Friborg, T., Hansen, B. U., Christensen, T. R., and Bay, C.: Trace gas exchange in a highArctic valley: 3. Integrating and scaling $\mathrm{CO}_{2}$ fluxes from canopy to landscape using flux data, footprint modeling, and remote sensing, Global Biogeochem. Cy., 14, 725-744, doi:10.1029/1999gb001137, 2000.

Sriskantharajah, S., Fisher, R. E., Lowry, D., Aalto, T., Hatakka, J., Aurela, M., Laurila, T., Lohila, A., Kuitunen, E., and Nisbet, E. G.: Stable carbon isotope signatures of methane from a Finnish subarctic wetland, Tellus B, 64, 18818, doi:10.3402/tellusb.v64i0.18818, 2012.

Stendel, M., Christensen, J. H., Marchenko, S., Romanovsky, V., Daanen, R., Rinke, A., Matthes, H., Kuhry, P., Rivkin, F., and Kaverin, D.: Size matters - very high resolution permafrost simulations on the $4 \mathrm{~km}$ scale in Northeast European Russia, EGU General Assembly 2011, Vienna, 2011.

van der Molen, M. K., van Huissteden, J., Parmentier, F. J. W., Petrescu, A. M. R., Dolman, A. J., Maximov, T. C., Kononov, A. V., Karsanaev, S. V., and Suzdalov, D. A.: The growing season greenhouse gas balance of a continental tundra site in the Indigirka lowlands, NE Siberia, Biogeosciences, 4, 985-1003, doi:10.5194/bg-4-985-2007, 2007.

Van Der Nat, F. W. A., Middelberg, J. J., Van Meteren, D., and Wielemakers, A.: Diel methane emission patterns from Scripus lacustris and Phragmites australis, Biogeochemistry, 41, 1-22, 1998.

Virtanen, T. and Ek, M.: The fragmented nature of tundra landscape, International Journal of Applied Earth Observation and Geoinformation, 27, 4-12, doi:10.1016/j.jag.2013.05.010, 2014.

Walter, K. M., Zimov, S. A., Chanton, J. P., Verbyla, D., and Chapin, F. S., 3rd: Methane bubbling from Siberian thaw lakes as a positive feedback to climate warming, Nature, 443, 71-75, doi:10.1038/nature05040, 2006.

Walter, K. M., Chanton, J. P., Chapin, F. S., Schuur, E. A. G., and Zimov, S. A.: Methane production and bubble emissions from arctic lakes: Isotopic implications for source pathways and ages, J. Geophys. Res., 113, G00A08, doi:10.1029/2007jg000569, 2008.

Webb, E. K., Pearman, G. I., and Leuning, R.: Correction of flux measurements for density effects due to heat and water vapor transfer, Quart. J. R. Met. Soc., 106, 85-100, 1980.

Whiticar, M. J.: Carbon and hydrogen isotope systematics of bacterial formation and oxidation of methane, Chem. Geol., 161, 291314, doi:10.1016/S0009-2541(99)00092-3, 1999.

Wille, C., Kutzbach, L., Sachs, T., Wagner, D., and Pfeiffer, E.-M.: Methane emission from Siberian arctic polygonal tundra: eddy covariance measurements and modeling, Glob. Change Biol., 14, 1395-1408, doi:10.1111/j.1365-2486.2008.01586.x, 2008. 